\title{
Literacy of Young and Adult People: A Reflection on the Program Literacy for All (TOPA), in the City of Vitória da Conquista, Bahia, Brazil
}

\author{
Oney Cardoso Badaró Alves da Silva, Sheila Cristina Furtado Sales \\ State University of Southwestern Bahia, Vitória da Conquista, Brazil
}

\begin{abstract}
The objective of this work is to present an outline of the theoretical review of a research entitled "Literacy of Young and Adult People: A Study on the Program Literacy for All (TOPA) in the City of Vitória da Conquista, Bahia." The research is inserted in the area of interest of public policies and education management, linked to the post-graduation program in education of the State University of Southwestern Bahia (UESB). The carrying out of this research was motivated by the following questions: 1. How has the program TOPA contributed to the reduction of illiteracy in the city of Vitória da Conquista, Bahia? and 2. How are the policies and practices developed at the program TOPA articulated? Therefore, the objective was to analyze the contributions of the program TOPA for the reduction of illiteracy and describe the actions developed by the program TOPA in the city of Vitória da Conquista. To this end, interviews were conducted and documents were analyzed. Finally, one observed that, preliminarily, the program has not been performing in the context of this city, with their actions as a whole.
\end{abstract}

Keywords: literacy, young and adults, public policies

\section{Introduction}

The debate about illiteracy in Brazil is old. However, every effort historically done for the solution of this problem has not exceeded the limits of the implementation of campaigns and literacy programs. The facts denounce that effective results of these programs have not been significant. Because it is a plural country, with regional and intra-regional differences, the country should consider these differences upon implementing of all educational policy if it wants to achieve its goals.

Regarding young and adults literacy, in 2003, the Ministry of Education (MEC) implemented the Program Literate Brazil (PBA), turned to the literacy of young, adult, and elderly people, considering this program as a possibility of accessing citizenship and the awakening of the interest in increasing schooling. This program initially prioritized the service for municipalities with the highest rates of illiteracy, but it is currently developed throughout the country. By joining the program, state and municipal governments are committed to implementing its actions, in order to ensure the continuity of the studies for those being literate in the regular school system.

Oney Cardoso Badaró Alves da Silva, M.A. candidate, member of the Study Group on History, Policy and Practice in Education of the Young, Adult and Older People, State University of Southwestern Bahia.

Sheila Cristina Furtado Sales, Ed.D., professor, leader of the Study Group on History, Policy and Practice in Education of the Young, Adult and Older People, State University of Southwestern Bahia. 
In order to give you an idea of the dimension of illiteracy in the Brazilian State, the program records a number of approximately 14,700,000 adults and young people served between 2003 to 2012 (MEC, 2013). In 2012, about 1,200,000 young and adult people were served by the PBA (MEC, 2013). The largest illiteracy rates in Brazil are found in the North and Northeast, regions with a large rural population, besides being composed by the poorest states in the country, where education, for many years in its history, was seen as something only for people who had possessions.

The education for young and adults, from the Guidelines Law LDB 9394/96, has become an integral part of the basic education and with the responsibility of municipalities, although in practice the benefits have barely been visible in society, because there is not yet a consolidated project for this type of education. So, in a lot of schools to this kind of public, sometimes, there are classes where the young and adults have classes in some improvised space. Thus, schools to young and adult people, sometimes, are a different kind school if are compared with other schools or public. This kind of school does not work because its students tending to continue in the illiterate condition.

The fact is that Brazil also has a very high rate of illiteracy. The Brazilian Institute of Geography and Statistics (IBGE) recorded in 2010 a rate of $13.6 \%$ of illiteracy, which corresponds to more than $16,000,000$ of the population of 15 years old or more. That number drops to about 14,000,000 in 2011. The study of these figures suggests that the absolute illiteracy rates are declining, but the number of functional illiterate ones, those who cannot use the written language as a social practice, is growing. This fact is related to the mechanical conception of reading and writing adopted in IBGE's re-censing. If it was considered as literate a person who could read and write with autonomy, these rates would be quite different.

In view of this problem, this work presents a part of a literature review of a research developed in the program Literacy for All (TOPA) in Vitória da Conquista, Bahia. The research is inserted in the area of interest of public policies and education management, linked to the program of post-graduation in education of the State University of Southwestern Bahia (UESB).

The carrying out of this research was motivated by the following two questions:

1. How has the program TOPA contributed to the reduction of illiteracy in the municipality of Vitória da Conquista, Bahia?

2. How are the policies and practices developed in the program TOPA articulated?

Based on these questions, one aimed to analyze the contributions of the program TOPA, in order to reduce illiteracy in Vitória da Conquista and describe the actions developed by the program TOPA in the city of Vitória da Conquista.

Although preliminary, it was found that the municipality has not developed actions, let alone implemented policies so that the young people, adults, and seniors who have been literate by the program, have their enrollment in regular schools guaranteed. What has often happened, then, is the permanence of these individuals in the same literacy classes. This fact denounces that the municipality has failed to fulfill with parts of the signed agreement, which is to ensure the enrollment of all students of TOPA in the elementary school, in the education for young and adults.

\section{Literacy Public Policies for Young and Adult People}

In recent years, more explicitly, literacy has been considered as a fundamental commitment to ensure the universal right to qualified education of young and adult people who, for different reasons or circumstances, did 
not have the opportunity or access to the process of basic schooling. To literate all people, as proposed in the international agreement, is a major challenge that countries still have to face, including Brazil.

Despite having a fairly high rate of illiterate people, Brazil is also a country that has presented significant educational advances in the last two decades. Brazil was able to institute pre-school, by requiring the enrollment of children aged four to five years; to institute the nine-year elementary school, making compulsory the enrollment of all children aged six years in the 1st year and, according to registers, it approaches the universalization of this stage of education; to expand the supply of professional education; to reduce the rate of illiteracy among the young and the adults; to increase the funding for education; among others.

According to Barcelos (2012), Ferreira (2009), Riquelme and Herguer (2010), and others, literacy has been considered as a fundamental commitment to ensure the universal right to the qualified education of young and adult people who, for different reasons or circumstances, did not have opportunity or access to the process of basic schooling in childhood or adolescence. Hence, Barcellos (2012), Ferreira (2009), and Riquelme and Herguer (2010) presented some reflections about public policies by supporting their arguments on the financing of education from the point of view that all people have the right to education and the interlocution by Clark (2012), Ferreira (2009), Gonçalves (2013), Oliveira (2011), among others.

Barcelos (2012) presented a reflection regarding public policies, always loaded with new concepts, laws, but devoid of new practices. In this respect, one always notices that the implementation of a given policy does not imply significant changes in the practices. These are not derived or based on the new epistemological conceptions. The result is almost always the continuity of old practices and consequent failure of the results.

It should be addressed, thus, that the literacy of all people aged 15 and over in the Brazilian context is a major challenge that the country still has to face. In an insistent way, the Brazilian government has been facing the problem of illiteracy with the deployment of urgent programs, which end up with the government. The most serious thing is that they start and extinguish these programs without the fulfillment of their goals, to present a positive balance, even though they have been spending the available resources.

These programs and/or policies fall more on what one might be called government policies than state policies, denouncing the historical neglect with this type of education. The illiteracy problem in Brazil is old and has being treated by emergency programs, which presents in their entirety the same structures and characteristics. As a result, this issue remains on the agenda of the discussions related to the public policies, especially, the educational ones.

Introduced since the 20th century, literacy programs, successively deployed in each government, confirm that the government's concern has turned more to its brand than to reducing illiteracy rates and the quality of the literacy offered to the population. The attention to teaching reading and writing, developed by means of the programs and the Brazilian school, was based more on political than pedagogical goals. As a result, Brazil has reached the second decade of the 21 st century with about $13,000,000$ illiterates among people aged 15 or more.

Oliveira (2011) presented a distinction between government policies and state policies:

It is considered that government policies are those that the executive decides in an elementary process of formulating and implementing specific measures and programs in order to answer the demands of the domestic political agenda, even if they involve complex choices. State policies, in turn, are those that involve more than one state agency, passing in general by the parliament or by various levels of discussion, resulting in changes of other pre-existing standards or provisions, which impact the broadest sectors of society. (p. 329) 
It is no use to adopt an education speech as a right for everyone and which invests in policies for its universalization. It can be seen, however, a precarious frame of public schools, especially in relation to teaching reading and writing, considering that the evaluations of basic education shows that children finish the first stage of elementary school without having known how to read and write, that is, without being literate. It is undoubtedly necessary to increase investments in education, but even more importantly, seriousness and responsibility in implementing these resources for the benefit of educational activities so that the goals can actually be fulfilled.

According to Riquelme and Herguer (2010):

The social debt in education is to the population aged 15 years or older who should have access to literacy and primary and secondary education, because for this group, these opportunities are not available. Governments and the international institutions cannot ignore this reality that has been highlighted by a number of studies that demonstrate the need for greater investment in education. (pp. 346-347)

The Guidelines Law and Education Basis from 1996 recognizes education as a right for all and includes the education of young and adults in basic education. Although education is a right for everyone, not everyone has had the right to learn, not all who enroll in the school learn to read and write, and not all who learn to read and write have schooling success. Even the government agencies recognize that:

[...] In Brazil, 35\% of illiterates have attended school. The reasons for the failure of the country in the literacy of their young people are several: poor-quality schools, especially in the poorest regions of the country and in the poorest neighborhoods of large cities; early work; low educational levels of their parents; unpreparedness of the school system to deal with this population. (National Institute of Educational Studies and Research Anísio Teixeira [INEP], 2007, p. 10)

One cannot deny that advances have happened in the education of young and adults, stimulated by the provision of the Federal Constitution and the National Educational Bases and Guidelines Law, in addition to the requirement, in the country's re-democratization times, to ensure social justice, regarding the right to education in order to overcome the compensatory offer idea and the challenge of seeking qualified education and equity for the individuals with rights, now recognized as such (Barcelos, 2012).

\section{Program TOPA: Historical Aspects and Perspectives}

In the State of Bahia, the education of young and adult people follows the logic of the Brazilian context, marked by marginalization within public policies. Their actions are coordinated not to solve the problem of illiteracy and/or increase the education of the adult population, but to soften the secular problem. In this sense, in order to contribute to overcoming these shortcomings, the State of Bahia, through the State Department of Education, implanted in 1996 the Literacy Program for Young and Adults (AJA BAHIA), which is considered one of the most important government actions in the area of education.

Similar to the national programs, AJA BAHIA intended to promote access to reading and writing for all those who had been excluded from the school system. Its goal was to reduce illiteracy throughout the state, relying, to this end, on the involvement of the 417 municipalities at the time. The prediction was to serve $1,000,000$ young and adult illiterates, thus, reducing by $40 \%$ the rate of illiteracy in three years.

As a basic strategy, the program predicts the continuation of students' literacy. To make this possible, a municipal center for mobilization was created for the identification of community needs, besides the institution of educational spaces that would provide conditions for the development of literacy. 
According to the proposed program, it should be ensured that the young and adult illiterate population have the right to literacy. This right meant that, in addition to learning to read and write and arithmetic, too, the analysis tools and reflection on reality, regarding the cultural expressions of each location are important for everyone. And, as noted above, guaranteed the continuity of studies for new literates.

The AJA BAHIA program adheres, in 2003, to the PBA, steadying, thus, partnership between the state government and the MEC. This adherence was very significant for Bahia, which had strengthened its program, accelerating, then, the serving of young and illiterate adults. In 2004, AJA BAHIA/PBA has partnered with universities, responsible for training teachers.

According to the MEC (2013), the impacts of the program AJA BAHIA and other programs implemented in the state reflected in the demographic census and National Survey by Household Sampling (PNAD), upon demonstrating a significant reduction in the illiteracy indicators in the population aged 15 to 24 years old. This meant a reduction from $20.6 \%$ to $7.7 \%$ of the illiterate population in this age group. The expectation at the time was that this program would provide changes in these people's lives, in order to promote a fight against poverty and social exclusion, besides broadening its social participation.

Although this program has brought such positive results according to MEC's information, it ended in 2006, along with the end of the government's mandate that implemented it. In addition, the state repeated the trend of what happens in the country: Young and adults' literacy has been on the margins of public policies and continues to be treated as emergency programs. Thus, in 2007, the governor of State of Bahia, at the beginning of his administration, announced that literacy of young and adults would be one of the priorities.

In 2007, IBGE reported that the State of Bahia, the fourth most populous state in Brazil, has about $14,100,000$ inhabitants (IBGE, 2007). Considering this population, the region where this state is located, and the socio-economic conditions of the people, it is admitted that, in figures, there are more than 1,800,000 young and adult people throughout the state in 2008, according to the PNAD. In the year of the institution of the TOPA, the State of Bahia presented, according to the PNAD, a rate of $16.8 \%$ of illiterate children aged 10 years or more.

Children's illiteracy occurs due to the fact that not all of them are in school, most who attend school do not learn to read and write even completing the 5th grade of elementary school, not to mention those who drop out because they believe that they are incapable of learning. These groups continue to make up a portion of illiterate young and adults.

According to the exposure presented above, it can be said that the State of Bahia was not an orphan in relation to educational services for young and adults. Besides the PBA that had included the state since 2003, as well as the programs of previous governors served, the state already had the state program AJA BAHIA, which only later partnered with the program of the federal government. So, the institution of the program TOPA was another state government program that even continued the practice of establishing a program rather than a public policy without emergency.

The institution of the program TOPA took place by means of the Decree 10.339 of May 9th, 2007, establishing within the State of Bahia, the special program for the literacy of the young and the adults: TOPA and other measures. In its 1st article, the decree has the following objectives of the program:

1. To reduce the illiteracy rates in the State of Bahia;

2. To promote qualified education, ensuring the entrance and stay in school of young people aged 15 or older and adults; 
3. To give the beneficiary the conditions that effectively help them in their social, political, economic, and cultural inclusion;

4. To provide young people and adults with professionalization alternatives integrated into the processes of literacy and schooling (Public Ministry of Bahia, 2007).

In order to implement the program, according to this decree, the state should formulate specific policies, projects, and operational standards to enter agreements for technical and/or financial cooperation with public right bodies and private right, and to train teachers and educators responsible for teaching activities related to the program and to publicize the program. The carrying out of this program, as planned, occurs with financial resources of the federal government, the State of Bahia, and the municipalities participating in the program.

Based on this decree, a significant difference is noted between this and the previous program. While the other was born as exclusivity of the state, in relation to its finances (only after a few years later did it partnered with PBA), TOPA was already born in partnership with the federal program, even because of the favorable partisan-political articulations to the state government that began in 2007. It is the PBA that finances the costs of training the literacy teachers and coordinators of classes, school supplies, school materials, foodstuffs (school meal), transportation of literacy teachers, teaching materials, eye exam for learners, scholarship for literacy teachers and classes coordinators, etc..

So, the program TOPA is structured according to the resolutions related to the PBA. The name change took place, thus, due to the change of the governor in the State of Bahia, adopting the same historical strategies of the country, as discussed above. TOPA, perhaps to mark their identity, differentiates itself from the PBA in relation to the hours of the initial training of 60 hours, while the PBA establishes 40 hours. The textbooks used at TOPA are also different from those used at PBA.

Under these conditions, the TOPA program is another public policy of the government to the educational service for young, adult, and elderly people who did not had the opportunity to learn to read and write in childhood. Thus, by the literacy process, this policy structured its political and pedagogical proposal so that these people could build their literacy basis in a significant and emancipatory way.

According to the Secretary of Education of Bahia, the program TOPA operates from the perspective of the social educational intervention. The motto of the secretariat is to respect the right to citizenship, learning and ensuring qualified education. The governor attests the continuing reduction of illiteracy and poverty in the state. The government's goal was to literate a million illiterate young and adult people in four years. In addition, the government ensured that all literates would have the guarantee to continue their studies.

To the secretary of state education, the importance of the offer to literate young and adult people is the improvement of social indicators. In this sense, one perceives as essential that governments, public managers, businessmen, social and union movements, community leaders, students, and volunteers are united by TOPA and believe that when all are in change happens.

The program TOPA lasts eight months, which corresponds to 360 credit hours. They are two and a half credit hours per day, from Monday through Thursday or two credit hours from Monday through Friday, according to the specificity of each community. The literacy teacher can have up to two classes with a minimum of 10 students in each class, in the case of the countryside, and at least 20 students in urban areas. The class coordinator can monitor up to eight classes in the countryside and 10 classes in urban areas. But the Libras interpreter/translator can accompany up to three learners per class. In compliance with the decree establishing the program TOPA, the government should formulate policies for achieving the goals. 
Therefore, the government has partnered with town houses, institutions, and organizations through the Secretariat of Education of the State of Bahia in order to guarantee the right to literacy for all illiterate young and adult people. Thus, one set as its general aim to promote qualified education for the population of young, adult, and elderly people, to ensure their entrance and stay at school, providing them the necessary opportunities for the appropriation of reading and writing and creating the objective conditions for these subjects' social, political, economic, and cultural inclusion.

The specific established aims of the program TOPA was to reduce the illiteracy rate in Bahia, ensuring the population aged 15 or more the necessary objective conditions for the continuation of their studies, to perform actions that contribute to the social and economic development of Bahia's population, to support Bahia's municipalities in the improvement of their educational indicators, to partner with municipalities in Bahia for the carrying out of the literacy program, and to articulate government and society in a political action in order to improve the living conditions of Bahia's population.

Among the actions developed by the program TOPA are studies and research, training of literacy teachers, besides the development of tools and monitoring and evaluation mechanisms, as well as the production of didactic and pedagogical material. According to the principles of the program, the challenge of eradicating illiteracy in the state, by means of public policies aimed at the education of young and adult people, who, according to the Secretariat of Education, follows the same principles of the state political and educational project.

The political pedagogical project TOPA also emphasizes the work as an educational principle and the link between education and work as themes, given that:

[...] There is an indissoluble relationship between work and education, which is based on the acquisition and production of knowledge by workers in/and for the work process. This is the basis for human societies, including the current knowledge society. Currently, more than never it means a strong relationship between technology and education. In order to enter the world of work it is necessary to understand and know how to apply technologies, which requires prior access to basic education. (Public Ministry of Bahia, 2009, p. 9)

Therefore, the methodological strategies of the program should take into account the strengthening of the political and educational awareness of all the individuals involved in the aforementioned program, in addition to mastering the reading, writing, and arithmetic operations. Based on this, TOPA's pedagogical political project emphasizes the need to develop teaching strategies in which the contents be drawn from reality.

\section{Final Considerations}

Given the rates of illiteracy, it can be said that all literacy policies for young and adult people in Brazil have failed because none of them managed to reach their goals. It is the result of the lack of state policies for the development of education projects that meet the population's needs, in this case, literacy. The programs, all of them, were emergency ones and did not bring with them the need to promote social transformation.

By means of these actions, as highlighted by Ferreira and Fonseca (2011), "The intention of the Ministry of Education is to integrate a set of programs to provide organicity to the national education system, mobilizing the whole society in order to improve the quality of education" (p. 64). However, it is necessary that the proposals contained in the Brazilian educational planning demonstrate effectiveness, and consequently, continuity. 
Addressing the problem of illiteracy, which is historical, by means of a program, means not giving priority to the country's public education. According to Gramsci (1997), literacy needs to be seen as a social practice linked to both the configuration of knowledge and power and the political and cultural struggle for language and for experience. Another aspect of these programs is to consider the literacy a mere learning technical skill of reading and writing. More than that, it is necessary to think literacy for young and adult people as a tool that not only gives condition for the individual to learn to read the world, but also to be able to write history.

For years, Brazil has struggled for the defense of a universal, compulsory, secular, and public education. It is recognized, however, that it still wishes to implement more serious policies and education projects committed to this education. In the specific case of the municipality of Vitória da Conquista, it was found, on a preliminary basis, that there has been no incentive nor has developed any action by the city, to ensure the continuity of the educational process.

Moreover, it was also possible to note the lack of coordination between policies and literacy practices; that literacy teachers are not qualified to the practice that they perform; the management of the program TOPA in the city takes place only in the bureaucratic aspects of filling in forms and reporting, without effectively occupying the educational and socio-cultural issues, such as the philosophy of the proposal. It is possible to predict, according to these problems present in the city that the result of this program, at least in the municipal context, the following of the trend of national programs, which is not to meet their targets.

\section{References}

Barcelos, L. B. (2013). Centro de estudos supletivos: O que é qualidade na Educação de Jovens e Adultos? (Supplemental study centre: What is quality in the youth and adult education?) Paper presented at The 36th National Meeting of ANPED, Goiânia. Retrieved from http://36reuniao.anped.org.br/

Brazilian Institute of Geography and Statistics (IBGE). (2007). Population count. Retrieved from http://www.ibge.gov.br/home/ estatistica/populacao/contagem2007/

IBGE. (2010). Map of illiteracy in Brazil. Retrieved from http://www.estadao.com.br/especiais/mapa-do-analfabetismo-nobrasil,142319.htm

Clark, G. N. (2012). Os sentidos da experiência de alfabetizar no Programa Todos Pela Alfabetização/Brasil Alfabetizado, em Rio Real-BA (The meanings of literacy experience in Literacy Program for All/Literate Brazil in Rio Real-BA). Retrieved from http://tede.ucsal.br

Ferreira, E. B., \& Fonseca, M. (2011). O planejamento das políticas educativas no Brasil e seus desafios atuais (The planning of educational policies in Brazil and their current challenges). Perspectiva, 29(1), 69-96. Retrieved from http://www.perspectiva.ufsc.br

Ferreira, L. O. (2009). O fórum mineiro de eja e a construção das políticas públicas em Belo Horizonte (The Minas Gerais’s forum on EJA and the construction of public policies in Belo Horizonte). Paper presented at The 32nd National Meeting of ANPED, Caxambu. Retrieved from http://32reuniao.anped.org.br/arquivos/trabalhos/GT18-5185-Int.pdf

Giroux, H. A. (1997). Os professores como intelectuais: Rumo a uma pedagogia crítica da aprendizagem (Teachers as intellectuals: Toward a critical pedagogy of learning). Porto Alegre: Artmed.

Gonçalves, L. G. (2013). A educação de jovens e adultos e a arte de pensar por alternativas (The education of young people and adults and the art of thinking for alternatives). Paper presented at The 36th National Meeting of ANPED, Goiânia. Retrieved from http://36reuniao.anped.org.br/

Gramsci, A. (1997). Intellectuals and the organization of the culture. Rio de Janeiro: Civilização Brasileira Press.

Ministry of Education (MEC). (2013). Programa Brasil Alfabetizado (Literate Brazil Program). Retrieved from http://portal.mec.gov.br

National Institute of Educational Studies and Research Anísio Teixeira (INEP). (2007). SAEB-Sistema nacional de avaliação da educação básica (SEAB — National system of basic education evaluation). Brasília: INEP. 
Oliveira, D. A. (2011). Das políticas de governo a política de estado: Reflexões sobre a atual agenda educacional Brasileira (Of government policies to state policy: Reflections on the current Brazilian educational schedule). Educação \& Sociedade, 32(115), 323-337. Retrieved from http://www.cedes.unicamp.br

Public Ministry of Bahia. (2007). Decreto 10.339, 09 de maio de 2007 (Decree 10.339, 09 May, 2007). Retrieved from http://governo-ba.jusbrasil.com.br/legislacao/75633/decreto-10339-07

Public Ministry of Bahia. (2009). Programa Todos pela Alfabetização-TOPA (Program Literacy for All—TOPA). Retrieved from http://www.sec.ba.gov.br/topa

Riquelme, G. C., \& Herger, N. (2010). Deuda social con la educación de personas jóvenes y adultas: Estimación de recursos necesarios (Social debt to the education of young people and adults: Estimation of necessary resources). Retrieved from http:// www.anpae.gov.br/trabalho 